\title{
Geologic field studies of the Miki Fjord Area, East Greenland
}

\author{
DENNIS K. BIRD, MINIK T. ROSING, CRAIG E. MANNING \& NICHOLAS M. ROSE
}

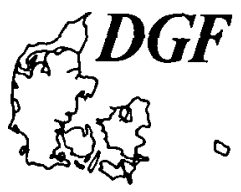

Bird, D. K., Rosing, M. T., Manning, C. E. \& Rose, N. M.: Geologic field studies of the Miki Fjord Area, East Greenland. Bull. geol. Soc. Denmark, vol. 34, pp. 219-236, Copenhagen, December, 20th, 1985. https://doi.org/10.37570/bgsd-1985-34-18

Field relations between Tertiary intrusions and the lithologic units near Miki Fjord provide a record of physical and chemical processes associated with crustal extension and the formation of the East Greenland continental margin.

At several localities the Precambrian basement has been remobilized and partly incorporated in the large macrodikes northeast of the Skaergaard intrusion. Blocks of vesicular basalts sank into the macrodike magma and were metamorphosed to equigranular aggregates of olivine and ortho- and clinopyroxenes with concentrations of plagioclase filling amygdale-like structures. We suggest that contact metamorphic dehydration of hydrous alteration minerals in the basaltic xenoliths and diffusion of this water into the macrodike magma were responsible for the abundant rhythmic layering that occurs near swarms of the xenoliths in a manner similar to that proposed by Taylor \& Forester (1979) and Mc Birney \& Noyes (1979) for the Skaergaard intrusion. Concentrations of xenoliths of leucogabbro and migmatitic basement gneisses are found near the top of one macrodike and in six smaller mafic dikes and sills that intrude the lower lavas. In contrast to the basalt blocks, the leucocratic xenoliths appear to have floated to the top of these mafic intrusions, thus providing an effective mechanism for transport of basement material during the early stages of crustal extension.

Basement rocks and Tertiary basalts of the area have undergone hydrothermal alteration that is concentrated in fracture systems near the intrusive bodies. Alteration mineralogy in the basalts consists of calc-silicate assemblages similar to those found in active geothermal systems in Iceland. Extensivecalcium metasomatism is evident in a number of coast parallel dolerite dikes that are mineralized by iron-rich prehnite. Thermodynamic analysis of the dehydration of prehnite to form epidote and gamet indicates that the fluids responsible for the formation of prehnite mineralized dikes were at temperatures less than about $250^{\circ} \mathrm{C}$.

Mineralized shear zones and mafic dikes of presumed Proterozoic age define a pronounced structural trend in the basement of the area. This east - west trend is parallel with the coastal dike swarm north of $68^{\circ} \mathrm{N}$ and with topographical trends within the basalts. We therefore suggest that the pre-Tertiary structures may in part control the deflection of the coastline at $68^{\circ} \mathrm{N}$ and other aspects of the Tertiary structural and intrusive development.

D. K. Bird, M. T. Rosing, C. E. Manning and N. M. Rose, Department of Geology, Stanford University, Stanford, California 94305, U.S.A. May 3rd, 1985.

Geologic relationships within the Miki Fjord area (fig. 1) provide information on the structural, metamorphic, hydrothermal and igneous processes associated with the early Tertiary development of the East Greenland continental margin. Within this area there are excellent exposures of the Precambrian basement gneisses, the Cretaceous-Tertiary sediments and the lowermost Tertiary lavas of the Blosseville Coast basalts. These lithologic units have been intruded by a number of mafic intrusions, such as the Skaergaard intrusion, macrodikes $(>100$ meter wide dikes) and a variety of thinner dikes including the coast parallel dike swarm. The structural, metamorphic and metasomatic modifications of the major lithologic units during the various intrusive events are recorded in the exposures within the Miki Fjord area.

The objectives of our research in this area are to evaluate physical and chemical processes associated with continental rifting that led to the formation of the North Atlantic ocean basin. Emphasis is placed on structural and chemical interaction of the major lithologic units with the mafic 


\section{EAST GREENLAND}

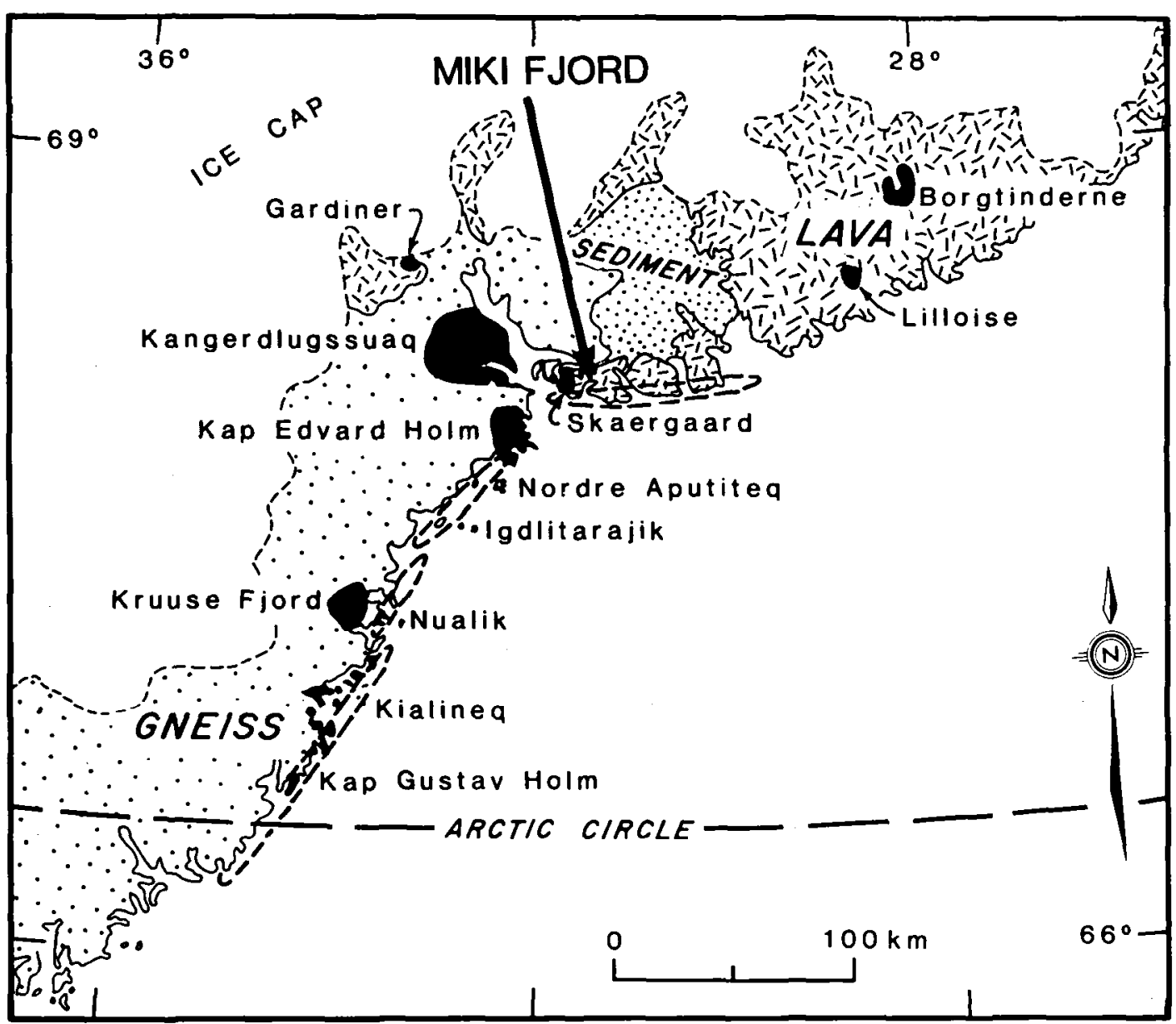

Tertiary intrusions

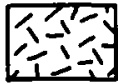

Tertiary lavas

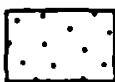

Archaean gneiss complex

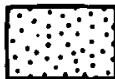

Cretaceous - Paleocene sedimentary rocks

\section{Basic dikes more than 50\% of outcrop}

Fig. 1. Schematic map of east Greenland showing major lithologic units along the coastal mountains and the inland nunataks. Place names and generalized locations of Tertiary plutonic complexes are shown in black, and the trend of the coast parallel dike swarm is represented by the elongate areas outlined by the broken lines. Lavas which outcrop from approximately $68^{\circ} \mathrm{N}$ along the coast represent the southernmost extent of the Blosseville Coast volcanic province. This map is summarized from information given by Wager $(1934 ; 1947)$, Wager \& Deer (1939), Brooks (1973), Myers (1980), Bridgwater et al. (1978a, b), and Brooks \& Nielsen (1982b). The study area is located at Miki Fjord east of the Skaergaard intrusion. 
intrusions and on the hydrothermal systems formed by the emplacement and cooling of gabbroic plutons and mafic dikes in East Greenland.

The present communication builds upon the previous studies of the geology of the Miki Fjord area reported by Nielsen et al. (1981) and recent studies of the subsolidus cooling history of the Skaergaard intrusion. Field studies at the Skaergaard intrusion have documented a number of mineralized fracture systems in both the intrusion and its host rocks (Norton, Taylor \& Bird 1984; Bird \& Rogers 1983; Rogers \& Bird 1983; 1984). Some of these fracture sets contain upper amphibolite facies metamorphic mineral assemblages that were formed during the early stages of the subsolidus cooling of the Skaergaard intrusion (Manning \& Bird 1983; Bird \& Rogers 1983; Bird \& Manning 1984). These fracture systems controlled the flow of hydrothermal solutions through the crystallized pluton and correspond to the paleo-permeability/porosity that is responsible for the $\delta^{18} \mathrm{O}$ mass transfer and predicted 0.01 to 0.1 millidarcy permeability of the cooling intrusion reported by Taylor \& Forester (1979) and Norton \& Taylor (1979).

The findings presented below demonstrate that there has also been extensive interaction between the upper crustal lithologic units and mafic intrusions within the Miki Fjord area. Hydrothermal metasomatism occurs within and near all the mafic intrusions and is superimposed on regional metamorphic mineral assemblages. Structural, textural and mineralogic relationships between upper crustal xenoliths in the mafic intrusions imply varying degrees of interaction that may have important consequences on the igneous petrogenesis of all these intrusions. These findings are presented below in the order of the timestratigraphic sequence of the major lithologic units in the Miki Fjord area.

\section{Precambrian basement}

The Precambrian basement of the area consists mainly of Archaean granodioritic to tonalitic orthogneisses interlayered with supracrustal rocks of sedimentary and volcanic derivation, and cut by later mafic dikes. It has been described in some detail by Wager (1934), Wager \& Deer (1939), Bridgwater et al. (1978a,b), and Kays et al. (1981). We have examined the gneiss terrain north of Miki Fjord, from its contact with the Cretaceous to early Tertiary sediments and inland at Issøerne (fig. 2).

\section{Metamorphism}

Small exposures north of Vandfaldsdalen, a valley extending due north from Eskimonæs (fig. 2), are granulite facies gneisses partially retrogressed to greenschist facies. Granulite facies grade was recognized by the occurrence of meter wide sheets of garnet-trondhjemite, the occurrence of partly chloritized garnets in the more mafic gneisses, and the local occurrence of "blebby texture", supposed to represent retrogressive recrystallization of granulite orthopyroxene (Bridgwater et al. 1978c).

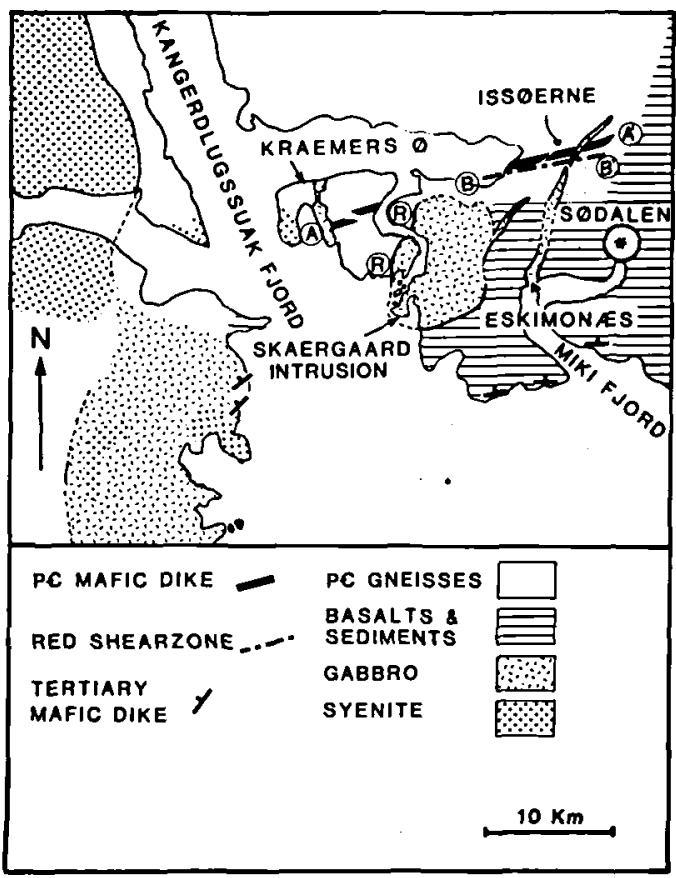

Fig. 2. Geological sketch map of the Kangerdlugssuak - Miki Fjord areas showing observed structures in the Precambrian basement north of Miki Fjord. The thick broken lines between A and A' denote en echelon sets of Precambrian mafic dikes, and the thin broken lines between $B$ and B' represents the location and trend of red microcline-quartz mineralized shear zones. Points marked $R$ west of the Skaergaard intrusion denote localities of red gneiss samples analyzed by Taylor \& Forester (1979). The general orientations of the Coast parallel dike swarms south and east of Kangerdlugssuak Fjord are shown by the strike and dip symbols. 
Metamorphic phase relations found near Iss $\emptyset$ erne suggest that the metamorphic conditions did not exceed amphibolite facies. The amphibolite facies gneisses consist mainly of grey tonalitic to granodioritic gneisses, with minor components of white granitoid gneiss. They resemble the gneisses of the Godthåbsfjord area (McGregor 1973) in many respects. The supracrustal sequences generally consist of garnetiferous metapelitic gneisses interlayered with minor mafic and ultramafic units represented by amphibolites and talc-schists. The supracrustals form belts mappable for several kilometers along strike and at least hundreds of meters perpendicular to the regional structural trend.

\section{Mafic dikes}

A set of large ( $<50$ meters wide) east-west trending mafic dikes can be traced on aerial photographs from Kraemers Island to Sødalenglacier, a distance of about 25 kilometers (see A-A' on fig. 2) In the field they were seen to cut all other pre-Tertiary units, and consist of amphibolites locally displaying steeply plunging mineral lineations. The dikes have linear trends and therefore postdate regional deformation but not regional amphibolite facies metamorphism. They are cut by structures and mineralization characterized by the red shear zones (see below) and by Tertiary dikes. In accordance with Bridgwater et al. (1978a) they are assumed to be of Proterozoic age.

\section{Red shear zones}

Within the amphibolite facies terrain, east-west trending zones of red-coloring of the gneisses were observed (see B-B' on fig. 2). The red-coloring is due primarily to extensive blastesis of $\mathrm{K}$ feldspar that is concentrated in elongate zones of extensive ductile and brittle deformation less than $\sim 250$ meters wide. Age relations between shearing and potash metasomatism are unclear. Aggregates of red colored feldspar identified by $\mathrm{X}$-ray diffraction as maximum microcline were seen in all basement lithologies, including the large mafic dikes of supposed Proteroxzoic age. Tertiary dikes crossing the red zones are surrounded by 0.5 meter wide halos of bleached rock, suggesting that the red coloring took place before intrusion of these dikes. The zones are also characterized by chloritization of biotite, and by veins and larger lenses $(<1$ meter wide and $<10$ meters long) of quartz - microcline mineral assemblages. The larger lenses contain decimeter size microcline crystals. An area of several square kilometers around the red zone at Issøerne is crosscut by sets of northwest trending millimeter wide red colored veins associated with brittle fracturing.

It could not be determined in the field whether the red mineralized zones represent local redistribution of potash or large scale fluid circulation and potash metasomatism in high permeable shear zones. The latter is likely in view of Taylor \& Forester's (1979) $\delta^{18} \mathrm{O}$ analyses of the Precambrian basement rocks near the Skaergaard intrusion. They have demonstrated that feldspars in red mineralized zones west of the Skaergaard intrusion are depleted by $\sim 1.5$ per mil relative to normal regional values of $\sim 6.5$ per mil $\delta^{18} \mathrm{O}$. The $\delta D$ values in chlorite from a Kraemers Island red zone is - 136 per mil suggesting extensive reaction of the gneiss with meteoric water. This also implies that the red shear zones acted as permeable structures for the flow of meteoric water. The chloritization of biotite associated with widespread formation of maximum microcline may represent potash mobilization associated with oxidizing fluids.

\section{Basalts}

The lavas of the Blosseville coast (fig. 1) are part of one of the world's largest flood basalt provinces (e.g. Basaltic Volcanism Study Project 1981). The stratigraphy of the Miki Fjord region, which represents the southernmost and deepest portion of this province, has been established by Wager (1934, 1947), Soper et al. (1976a, b) and Nielsen et al. (1981). The earliest Phanerozoic rocks in the area are Cretaceous - Tertiary sediments of the uppermost Ryberg Formation unconformably overlain by Early Tertiary sediments and basalts that comprise the Vandfaldsdalen and Miki Formations. These give way to the thick sequence of tuffs of the Hængefjeldet Formation, which are in turn overlain by plateau basalts of the Irminger Formation. Rocks of the latter two formations were not examined in detail in this study. 
Metamorphic mineral assemblages in the basaltic rocks display a systematic regional zonation that correlates with stratigraphic depth. These assemblages are therefore of probable burial metamorphic derivation, in the sense of Coombs (1961). Localized contact metamorphism caused by hydrothermal convection and conductive heating associated with large intrusive bodies such as the Skaergaard intrusion and the macrodikes can be distinguished from the burial metamorphic assemblages based on the phase relations and modal abundances of metamorphic phases.

\section{Burial metamorphism}

Basaltic flows, tuffs, breccias and hyaloclastites of the Vandfaldsdalen Formation contain greenschist and prehnite-actinolite, (Liou et al., 1985) facies metamorphic mineral assemblages that may include varying amounts of prehnite, quartz, epidote, albite, actinolite, chlorite, hematite and calcite. The modal abundance of prehnite is usually higher than that of epidote in these rocks. Prehnite and epidote commonly occur in vugs and vesicles as botryoidal clusters or aggregates with quartz prisms. In contrast to the dark green iron-rich hydrothermal prehnite found within altered dikes and sills (see below), prehnite in the Sødalen area is light green in color, possibly indicating low ferric iron content. Chalcedony can be found in large vesicles and fractures near the top of the Lower Vandfaldsdalen Formation and in some rocks above this. Textural evidence usually indicates that calcite is the last mineral to form in these vugs. Variations in modal abundance of secondary minerals both within and between units were observed throughout the area. These variations include changes in the proportions of epidote, prehnite, chlorite, quartz and hematite. Occurrences of native copper together with epidote, prehnite and quartz in vesicles in the lavas of the Vandfaldsdalen Formation are common. Similar native copper assemblages have been observed in the northern portions of the Blosseville Coast (C. K. Brooks personal communication 1983). Numerous weathered and oxidized green copper-stained zones were observed on cliff faces near Miki Fjord.

Amygdale filling minerals found in the overlying Miki Formation include epidote, prehnite, chlorite, chalcedony, quartz and zeolites. Euhedral trapezohedra of analcime up to one centimeter in size occur in some vesicles. Pumpellyite occurs in tuffs at Hængefjeldet (C. K. Brooks personal communication 1984), and chalcedony, scolecite and stilbite are found in the plateau basalts in this area (Nielsen et al. 1981). Higher up in the stratigraphic section in the Scoresbysund area, Fawcett et al. (1973) report quartz, calcite and a wide variety of zeolites. The latter authors note that amygdales in the uppermost flows contain no zeolites.

The total thickness of the Cretaceous - Tertiary section in the Sødalen and I. C. Jacobsen Fjord area (fig. 8) is unknown, but reconstructions range from about 4.5 kilometers (e.g. Nielsen \& Brooks 1981) to nine kilometers (Soper et al. 1976b). Fluid inclusions in quartz veins from near the Skaergaard intrusion yield homogenization temperatures ranging from $275^{\circ} \mathrm{C}$ to $340^{\circ} \mathrm{C}$ with a mode of $300^{\circ} \mathrm{C}$ (Bird \& Rogers 1983). These temperatures indicate that the minimum regional geothermal gradient must have been at least $33^{\circ} \mathrm{C}$ per kilometer if the lave pile was nine kilometers thick. However, the estimate of 4.5 kilometers (Nielsen \& Brooks 1981) may be more appropriate because it accounts for crustal thinning due to widespread normal faulting in the area. Thus a better estimate of the minimum geotherm is probably closer to $66^{\circ} \mathrm{C}$ per kilometer. The presence of prehnite in metamorphic mineral assemblages indicates that temperatures in the lowermost rocks in the Miki Fjord area, with 4.5 kilometers of overburden, could have been no higher than approximately $400^{\circ} \mathrm{C}$ (Liou 1971; see below) which yields a maximum geotherm of $90^{\circ} \mathrm{C}$ per kilometer. Kuniyoshi \& Liou (1976) postulate a geotherm of about $50^{\circ} \mathrm{C}$ per kilometer for the flood basalts of Vancouver Island, British Columbia, Canada. Considerably higher geothermal gradients of $>100^{\circ} \mathrm{C}$ per kilometer for oceanic rift environments have been inferred from ophiolites (e.g. Evarts \& Schiffman 1983). The estimates of the regional geotherm for the lavas of the Blosseville coast probably lie between these two, perhaps reflecting elevated heat flow associated with rifting and the formation of oceanic crust. 
Contact and hydrothermal metamorphism

The most continuous exposures of the contact of the Skaergaard intrusion with its host basalts occur along its eastern contact (cf. Wager \& Deer 1939). Rocks along the eastern contact are depleted in ${ }^{18} \mathrm{O}$ relative to basalts further away from the Skaergaard intrusion (Taylor \& Forester 1979), and thus were altered by circulating meteoric water associated with the cooling of the pluton. Mineralized fractures (veins) are more abundant near the intrusion in the western Vandfaldsdalen area than elsewhere in the Miki Fjord region. Vein abundances measured along $<50$ meter long traverses decrease from $>10$ veins per meter at the contact to $\sim 1.5$ veins per meter at a distance of 1.5 kilometers east of the Skaergaard intrusion.

A regionally extensive open-space breccia of probable hydrothermal origin occurs within the volcaniclastic breccia unit $\mu$ (Nielsen et al. 1981) and locally in the overlying flow units of the upper Vandfaldsdalen Formation. It is underlain by 20-30 meter thick sills. The breccia is exposed over several square kilometers just east of the Skaergaard intrusion and has been observed at similar stratigraphic levels at the head of I. C. Jacobsen Fjord. It is characterized by intense fracturing and brecciation of the Upper Vandfaldsdalen Formation and bleaching of the lavas and volcaniclastic breccias to pale grey colored, homogeneous textured rocks. Veins and pores are partially filled with dark green prehnite, chlorite, actinolite, albite and quartz. The large regional extent of this breccia, coupled with the observation that in several places amphibole veins associated with the cooling of the Skaergaard crosscut the breccia (see below), indicate that this hydrothermal activity was probably associated with high level sill emplacement below breccia unit $\mu$ before the intrusion of the Skaergaard magma.

Within 10 to 20 meters of the intrusion, black amphibole mineralized veins are abundant, metabasalts are recrystallized to anhydrous mineral assemblages and, in volcaniclastic breccias, clasts are elongate and stretched parallel to the contact. With the exception of irregular quartz veins that are formed parallel to the intrusive contact, the most abundant hydrothermal fracture systems are oriented perpendicular to the pluton contacts
(Bird \& Rogers 1983). In units of the Vandfaldsdalen Formation further from the contact, grandite garnet is found in addition to mineral assemblages similar to those in Sødalen. However, in contrast to the Sødalen area, the modal abundance of epidote is higher than that of prehnite in western Vandfaldsdalen.

\section{Macrodikes}

Several large layered gabbroic dikes outcrop east of the Skaergaard intrusion (Wager 1934). They strike northwest, parallel to the structural trend of the Tertiary plutonic centers and dike complexes exposed along the Greenland coast between $66^{\circ} 30^{\prime} \mathrm{N}$ and $68^{\circ} \mathrm{N}$ (figs. 1, 2). The dikes outcrop over a distance of about 20 kilometers from Miki Fjord to the gneiss nunataks northeast of Sødalen. They crosscut the metamafic dikes and red mineralized shear zones found in the gneiss terrain. Geochemical and structural features of these 100 to $>1000$ meter wide dikes have been summarized by Deer (1976). We have noted several features within and near the dikes that provide new insight on their igneous petrogenesis, mode of emplacement and the hydrothermal systems associated with their subsolidus cooling histories.

\section{Contact relations with host rocks}

The Miki Fjord macrodike has complex contact relations with the Precambrian gneisses near Issøerne. Intense metamorphism and deformation of the gneisses occur up to 10-20 meters from the contact. Bleaching of the felsic gneisses is apparent near these contacts, with evidence of various stages of partial melting and remobilization of the wall rock gneisses. Isoclinally folded, rustcolored biotite gneisses near the contact have been injected with partially melted felsic gneisses. Melting of the gneissic host rock is also evident from the field relations shown in fig. 3. The macrodike gabbros form rounded pillow type structures less than one meter in diameter within the host rock gneisses. These types of deformational and metamorphic features have not been observed at the contact between the larger Skaergaard intrusion and the basement gneisses.

Intense ductile deformation of lithic clasts of 


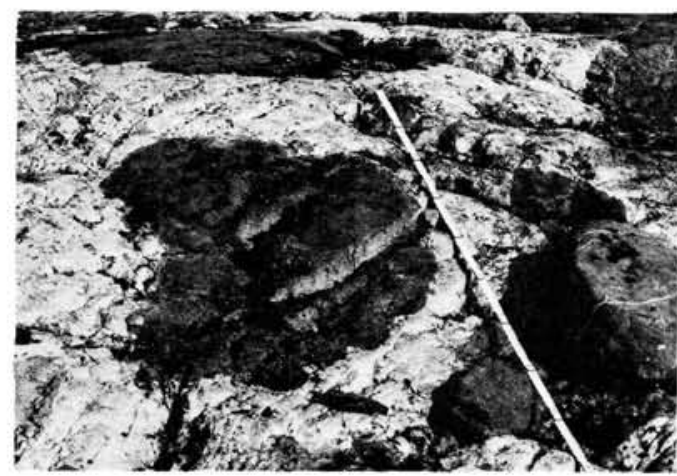

Fig. 3. Photograph of the contact between the Sødalen macrodike and the Precambrian gneisses east of Issøerne. Basement gneisses are remobilized and contain pillows of macrodike gabbros that are generally less than one meter in diameter. These types of pillow structures are restricted to $10-20$ meters from the country rock - macrodike contact. Scale is 0.9 meters long.

breccia unit $\mu$ of the Vandfaldsdalen Formation of the lower lavas occurs up to 0.5 meters from the contact of the macrodike at the northern end of Vandfaldsdalen. These breccia clasts are elongate parallel to the intrusive contact. In this area discontinuous, wavy quartz veins occur parallel to the macrodike contact in the breccia unit 2 to 3 meters from the contact. Amphibole mineralized veins perpendicular to the contact cross-cut the chilled margin of the macrodike and the elongate clasts in the breccia unit. Similar features have been observed at the contact of the Skaergaard intrusion with the host lavas.

\section{Internal structures}

As noted by Deer (1976), the macrodikes display well-developed rhythmic banding of ferromagnesian-rich layers of 2 to $10 \mathrm{~cm}$ thickness alternating with layers of gabbro of 5 to $100 \mathrm{~cm}$ thick (fig. 4A). In general, the layering is restricted to the upper stratigraphic levels of the exposed macrodikes and dips inward toward the center of the dike forming a broad trough parallel to the length of the dike. Deformation of the layering, possibly prior to the complete solidification of the intrusion, was noted at several locations. On the cliff east of peak 1020 north of Vandfaldsdalen (see Nielsen et al. 1982 for peak locations), slumptype features and apparent ductile deformation of the banding can be seen near vertical structures that appear to represent fault zones active just after the emplacement and solidification of the intrusion (cf. Deer 1976). Trough band structures are apparent in the macrodike at Issøerne on the east-facing cliffs of peak 656. Xenoliths of metabasalt have been observed in the macrodike as far inland as one kilometer north of Issøerne. This is several kilometers from the basalt - basement contact and at least several hundreds of meters below the projected base of the lower lavas, and demonstrates that the metabasalt blocks were sinking into the macrodike liquid. Picritic xenoliths similar to those found in the Marginal Border Group of the Skaergaard intrusion (Kays \& McBirney 1982) are more abundant than metabasaltic xenoliths northeast of Issøerne.

There appears to be a direct correlation between the intensity of the igneous layering and the abundance of basaltic xenoliths in the macrodikes. A similar correlation between xenoliths and igneous layering has been noted by McBirney \& Noyes (1979) and McBirney (1979) within the Layered Series of the Skaergaard intrusion. In many cases the basalt blocks in the macrodikes are incorporated into the mafic layers (fig. 4B) rather than deforming or deflecting the layering like some Upper Border Group xenoliths found in the Middle Zone gabbros of the Skaergaard intrusion.

On the ridge northeast of Eskimonæs, the Miki Fjord macrodike locally consists of greater than $50 \%$ basaltic xenoliths with minor anorthositic and leucogabbro xenoliths. Magnetite is abundant in selective layers in the well-developed rhythmic banding that incorporates the smaller blocks and drapes over the larger blocks forming crudely shaped trough band structures. A magnetite-rich lens 0.3 meters thick and 9 meters long rich zone surrounded by a 0.1 to 0.3 meter wide plagioclase also occurs at this locality. This lens appears to have intrusive contacts with the layered gabbro.

A sample of a basalt xenolith from the Miki Fjord macrodike near Eskimonæs provided by $\mathrm{T}$. F. D. Nielsen of the Geological Survey of Greenland (GGU) is an olivine-clinopyroxene-plagioclase granulite similar to that described by Wager \& Deer (1939:199) from a basalt block in the Layered Series of the Skaergaard intrusion. Amygdale like structures in the basalt blocks are equigranular aggregates of plagioclase 


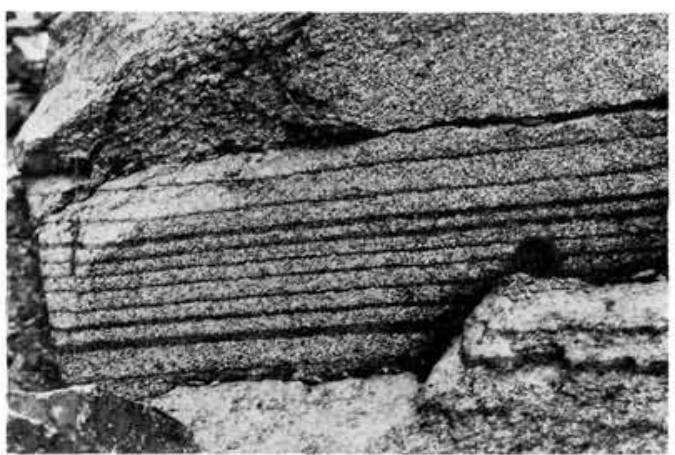

A

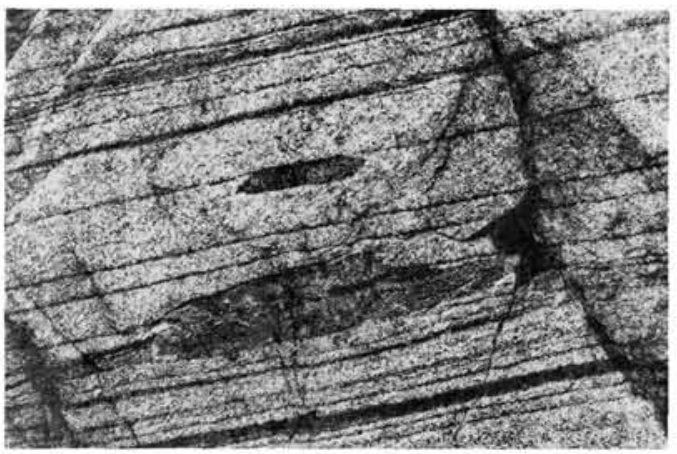

B

Fig. 4. (A \& B). Photographs of layering and metabasalt xenoliths in the Miki Fjord Macrodike northeast of Eskimonas. Lens cap is 50 millimeters in diameter.

$\left(\mathrm{X}_{\mathrm{CaAl}_{2} \mathrm{Si}_{2} \mathrm{O}_{8}}=0.62\right)$ and the matrix consists of aggregates of olivine and clinopyroxene that contain about 20 mole \% total iron. These mineralogic features of the basalt xenoliths probably formed by dehydration of hydrothermal and/or regional metamorphic minerals that are now found in the host lavas such as epidote, prehnite, chlorite and zeolites. It is likely that water produced from the dehydration of these minerals had a prominent role in the formation of the mineralogic layering found associated with large concentrations of the basaltic xenoliths in the macrodikes. Water would locally increase the rates of crystallization and diffusion of chemical components in the magma. This would favor the formation of in-situ mineralogic layering governed by the relative rates of chemical and thermal diffusion during cooling of the magma as proposed by McBirney \& Noyes (1979). Release of water from the metamorphosed basaltic blocks would also cause oxidation of ferrous iron in the magma, resulting in the deposition of magnetite near the blocks. The rare basaltic xenoliths in the Layered Series gabbros of the Skaergaard intrusion are associated with extreme $\delta^{18} \mathrm{O}$ depletions both in the xenolith and in the adjacent layered gabbros. This is believed to be the result of oxygen exchange with water derived from dehydration of hydrous alteration minerals in the basalt block (Taylor \& Forester 1979).

\section{Hydrothermal alteration}

Hydrothermal alteration of the macrodikes consists primarily of rust-colored amphibole, chlorite or serpentine mineralized fracture systems. There is a higher frequency of these types of fractures in the areas of abundant basalt xenoliths and near the contacts of the macrodikes with the lower basalts. Epidote and prehnite mineralized veins are rare in the macrodikes, and appear to be restricted to later shear zones. Alteration of the host rock basalts consists of a variety of mineralized fracture systems that contain calc-silicates including epidote, prehnite or garnet.

\section{Gneiss xenolith dikes}

L. R. Wager (1934) noted the occurrence of four dikes containing angular fragments of gneiss in the "metamorphic complex" near Kap Gustav Holm. He suggested that the gneiss inclusions were floating in the basic melt at the time of dike injection because they are concentrated near the top of the dikes.

Six dikes and low angle intrusions that contain felsic inclusions (fig. 5) were observed in the basalts east of the Skaergaard intrusion. These xenoliths are invariably concentrated in the center of dikes and at the top of low angle intrusions (figs 6,7). Some of these xenoliths have compositional banding and a gneissic fabric.

The xenoliths can be divided into at least five groups:

1. Felsic gneisses, unmodified relative to basement gneisses.

2. Homogeneous fine-grained felsic inclusions.

3. Medium-grained granoblastic plagioclase quartz rocks. 


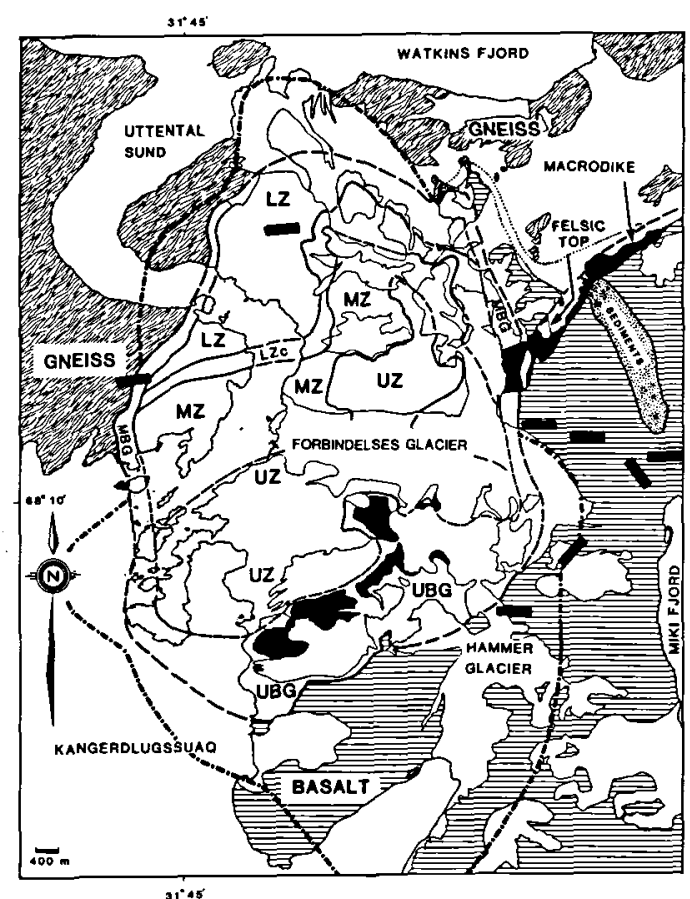

Fig. 5. Distribution and orientation of gneiss xenolith dikes within and near the Skaergaard intrusion. Dikes are shown with thick bars (not to scale). The thin broken line represents the surface outcrop of the Skaergaard intrusion (Wager \& Brown 1967), and the thick dot-dash line is the inferred maximum lateral extent of the intrusion based on gravity surveys of Blank and Gettings (1973) and reported by McBirney (1975). The major lithologic units of the Skaergaard intrusion are given by the abbreviations: $\mathbf{M B G}=$ Marginal Border Group, $\mathbf{L Z}=$ Lower Zone, $\mathrm{MZ}=$ Middle Zone, $\mathrm{UZ}=$ Upper Zone, $\mathrm{UBG}=$ Upper Border Group.

\section{Recrystallized vesicular basalts.}

5. Leucogabbro.

The second group of inclusions is interpreted as representing granitoid melts, formed by partial fusion of gneiss inclusions, whereas group 3 is regarded as the complementary residue. Group 5 is found in a dike positioned immediately above the gravity anomaly east of the Skaergaard intrusion interpreted by Norton et al. (1984) as a tongue of gabbro intruded along the basement-basalt interface. Plagioclase in this xenolith contains 65 mole $\% \mathrm{CaAl}_{2} \mathrm{Si}_{2} \mathrm{O}_{8}$, comparable to values found in cumulate type anorthosites (Simmons et al. 1980). Leucogabbro xenoliths have also been noted by C. K. Brooks (personal communication 1985 ) in a dike located in the western portion of the Skaergaard Layered Series. These leucogab- bro inclusions could represent Hidden Zone Skaergaard cumulate or fragments of Precambrian leucogabbro - anorthosite derived from the basement.

A large sedimentary block in the macrodike at the east contact of the Skaergaard intrusion (fig. 5 ) is shown on the geological maps by Wager \& Deer (1939) and Nielsen et al. (1981). Our field investigations have confirmed that it is spatially constrained to the top of the macrodike, as noted by Wager (1934) and Wager \& Deer (1939). However, it consists of group 3 inclusions set in a fine grained felsic matrix. The boundary with the underlying macrodike gabbro is sharp but wavy, with mutual apophyses. The pyroxenes in the gabbro near the contact are skeletal and form up to $20 \mathrm{~cm}$ long aggregates. We interpret the felsic

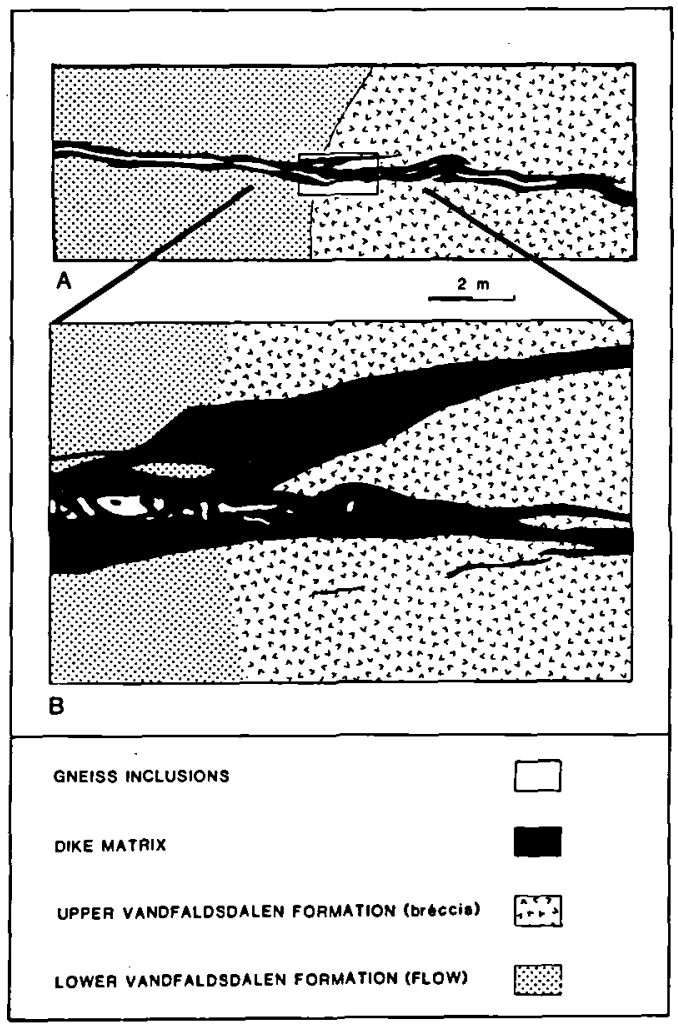

Fig. 6. Survey maps of the surface outcrop of an east-west trending gneiss xenolith dike located 1.5 kilometers east of the Skaergaard intrusion (see fig. 5). The dike transgresses the boundary between a flow unit and a breccia unit of the Vandfaldsdalen Formation. (A) The open areas in the mafic dike represent areas that contain gneiss xenoliths (typically greater than $50 \%$ xenoliths with average size of about 10 to 30 centimeters). (B) Sketch showing the individual xenoliths. 

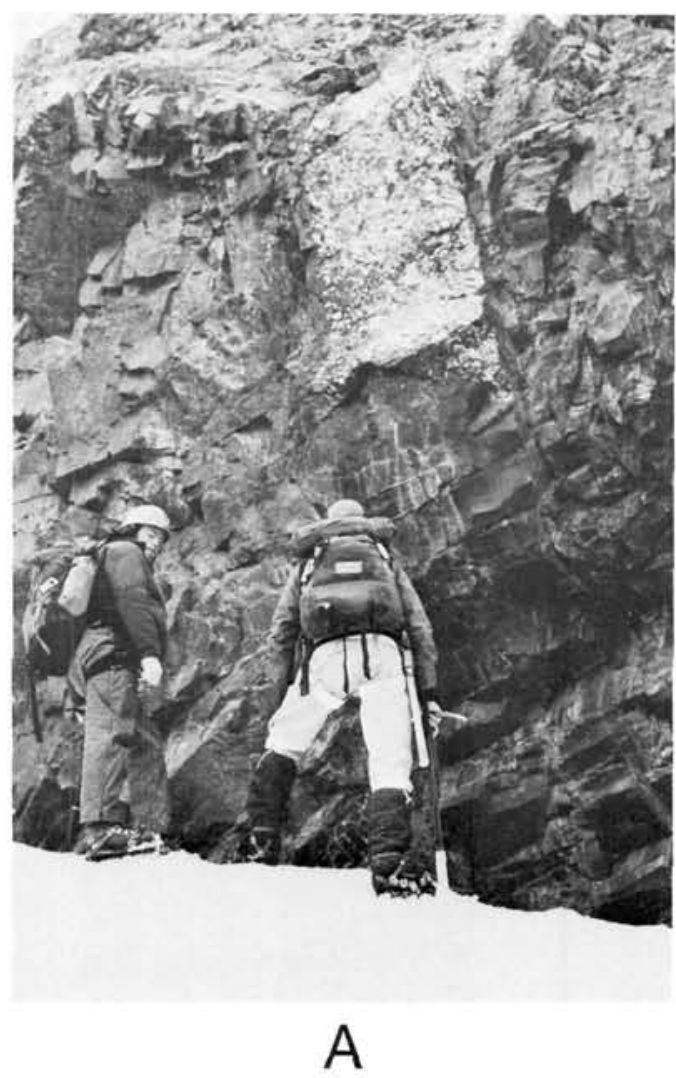

Fig. 7. (A) Photograph of gneiss xenoliths within the central portion of a 1 meter wide mafic dike east of the Skaergaard intrusion. (B) A 3 meter wide dike on the south west face of Hammertoppen near Hammer Glacier. The dike is located about 30 meters south of the contact of the Miki Formation ba-

top of the macrodike as having formed by a buoyant magma composed of a granitic melt plus restite xenoliths derived by remobilization of the basement.

The observation that gneissic xenoliths are transported towards the tops of mafic dikes supports the hypothesis of Norton et al. (1984) that the feeder pipes of the Skaergaard magma chamber eroded approximately $\sim 60 \mathrm{~km}^{3}$ of basement gneiss that was rafted to the top of the magma chamber, or fused and entrained in the magma as immiscible liquid. It also suggests that these dikes, as well as dikes with no inclusions at the present level of erosion, may have acted as pathways for remobilized material. The large proportion of fused material in some dikes suggests that there was an active flow of magma through the
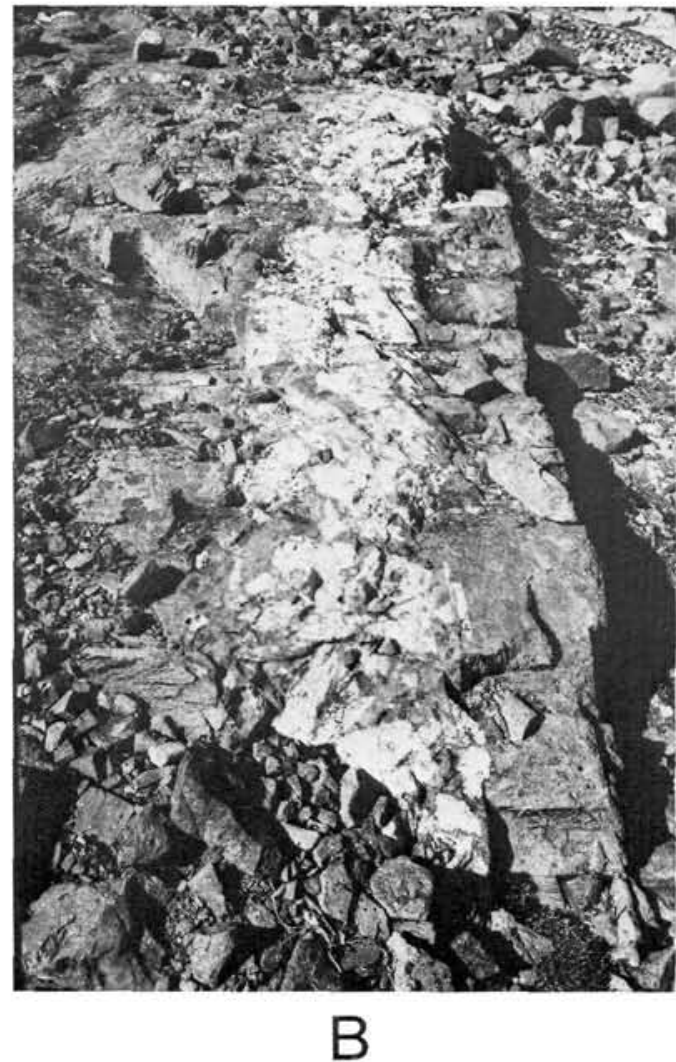

salts with the Skaergaard intrusion. Note the concentration of gneiss xenoliths at the top of this 3 meter wide dike, and the sharp contact between the portion of the dike containing greater than $70 \%$ felsic xenoliths and the essentially xenolith-free lower portion.

fissures, and perhaps that these dikes vented at the surface.

There is a striking correlation among a number of topographic, structural and intrusive features which suggest that the distribution of gneiss xenolith dikes is related to the deep structure of the area. A notable east-west trending topographical trough is represented by Forbindelses Glacier, the east arm of Miki Fjord and the glacier connecting Miki Fjord and I. C. Jacobsen Fjord (figs. 5, 8). Within this topographical low, Blank \& Gettings (1973) have identified a gravity high that probably represents the feeder conduit for the inflation of the Skaergaard intrusion (Norton et al. 1984) and a small protrusion of the eastern and western margins of the magma chamber near the basalt-basement unconformity. The gneiss 
xenolith dikes are found primarily within this east-west trending structure near the Skaergaard intrusion, and are either parallel to the structure or to the margins of the Skacrgaard intrusion as shown in fig. 5. This lineament and related high angle faults (Nielsen 1975) may reflect a deep structure within the underlying Precambrian basement. The inferred structure would be parallel to the mafic dikes and the red shear zones in the basement near Issøerne, and would probably share a common tectonic and rheological control.

\section{Coastal dike swarm}

The coast parallel dike swarm represents a major intrusive complex in East Greenland (Wager and Deer 1938; Larsen 1978). Despite some controversy as to its structural characteristics, most authors agree that it was associated with the extensional tectonism that took place during early opening of the North Atlantic ocean (Brooks 1973; Nielsen 1975, 1978; Bridgwater et al. 1978a, b; Faller and Soper 1979; Larsen 1980; Myers 1980; Nielsen \& Brooks 1981; Brooks \& Nielsen 1982a, b). During the summer of 1984 we visited a number of localities in the coastal dike swarm between Kap Irminger $\left(30^{\circ} 55^{\prime} \mathrm{W}\right)$ and Hængefjeldet $\left(31^{\circ} 45^{\prime} \mathrm{W}\right)$ and mapped in detail at several outcrops the interrelationship and relative ages of dikes and hydrothermal mineralized fractures. Alteration mineralogy may include prehnite, epidote, quartz, garnet, calcite and zeolites. These minerals commonly occur in veins or vugs, although in some cases dike centers are completely replaced by secondary minerals as described below.

Evidence for extensive calcium metasomatism has been found within dolerite dikes at several localities between Kap Irminger and the Skaergaard intrusion (fig. 8). These dikes have a distinctive speckled appearance resulting from relict igneous clinopyroxenes set in a matrix of prehnite which has formed by replacement of plagioclase and groundmass. A prehnite mineralized dike on the north shore of Miki Fjord was identified by C. K. Brooks and T. F. D. Nielsen in 1979. The ease with which we found five similar dikes suggests that they are widespread within the coast parallel dikes in this part of east Greenland.

Prehnite mineralized dikes are usually the

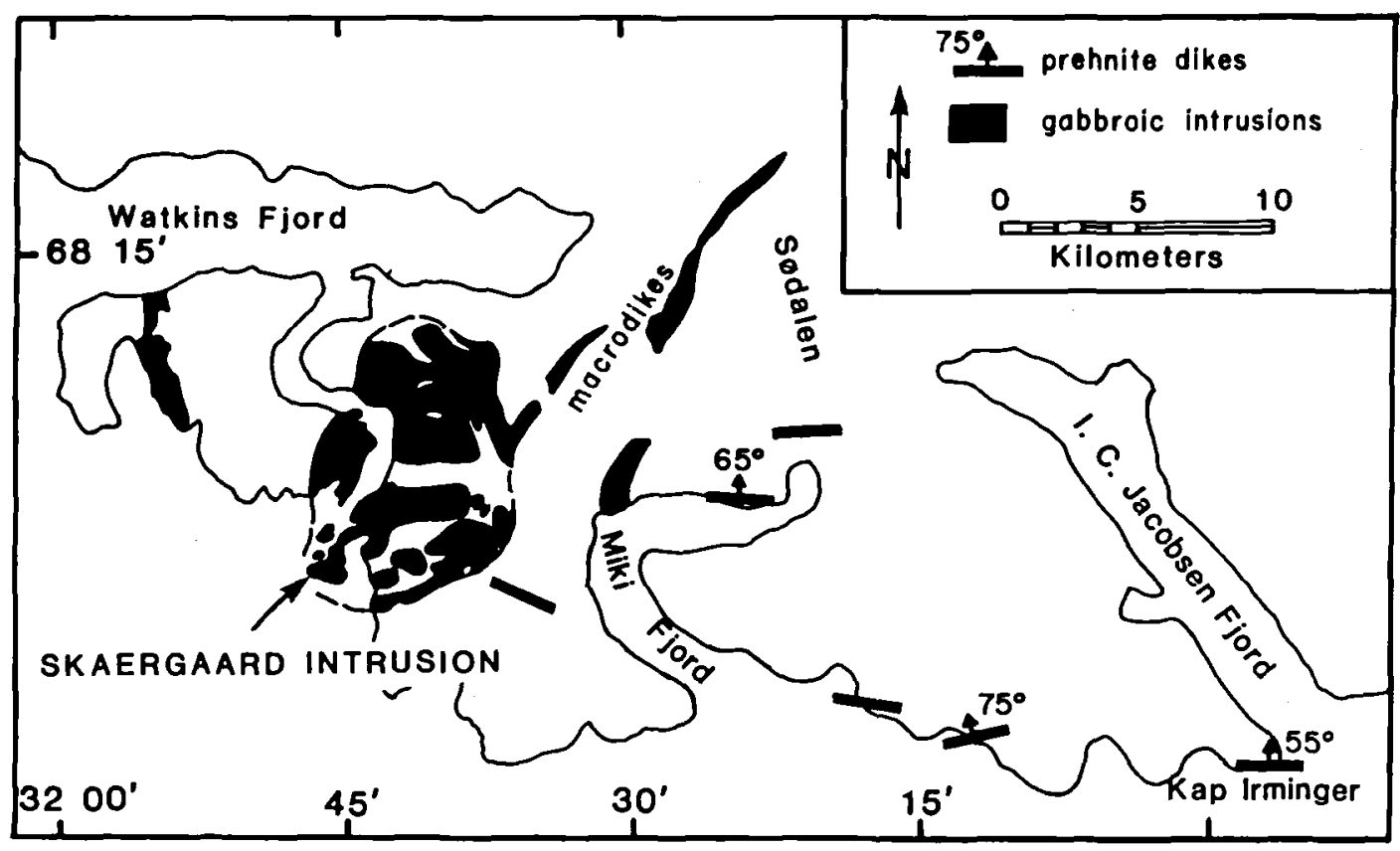

Fig. 8. Map of the distribution and orientation of known prehnite mineralized dikes between Kap Irminger and the Skaergaard intrusion. 


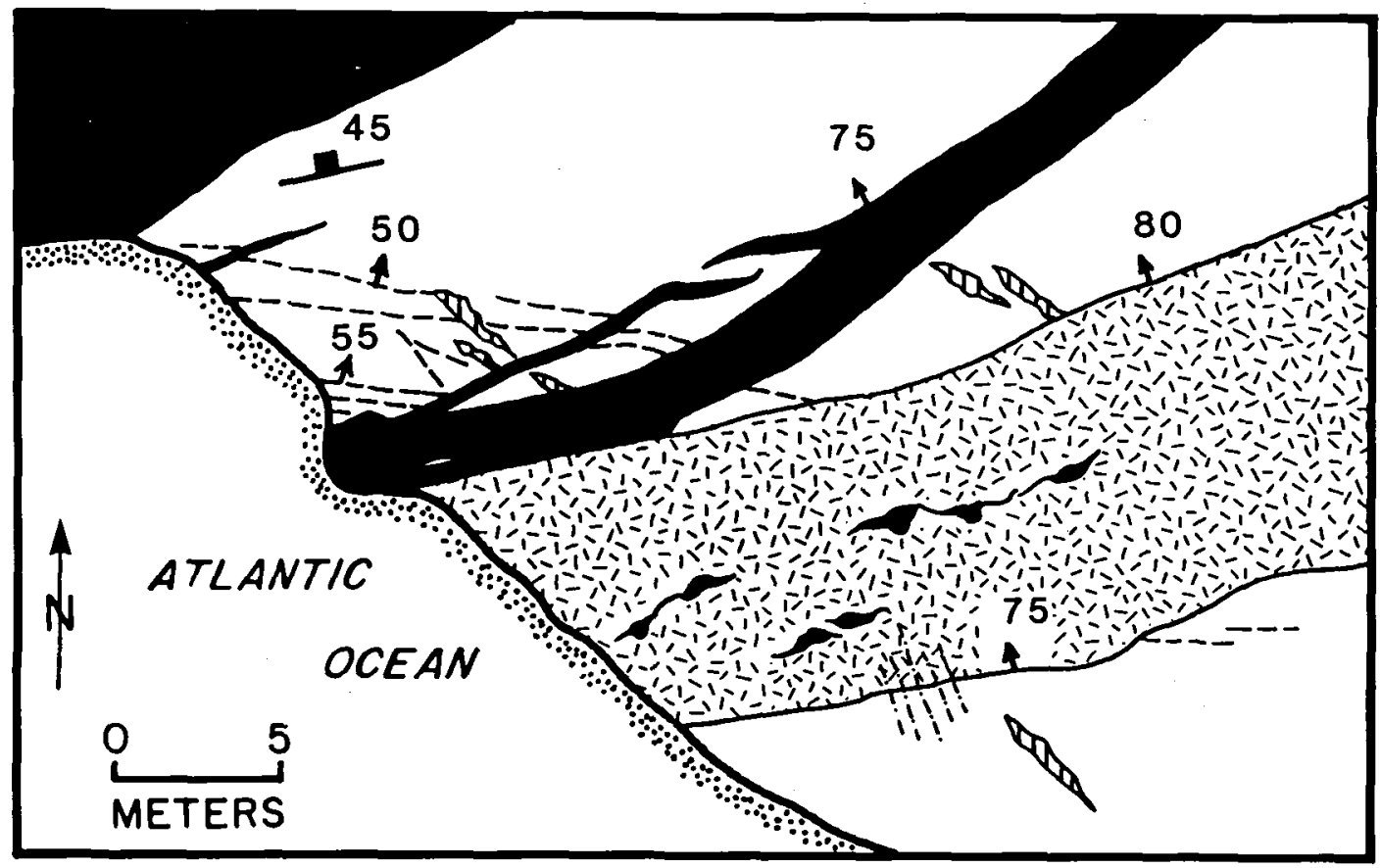

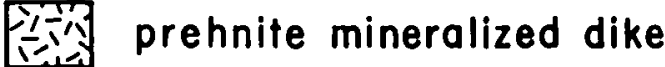

\author{
basalt dike
}

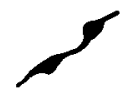

prehnite lined
cavities

\section{plateau basalts}

$-^{45}$ strike and dip of lavas

\section{5 dip of veins or contacts}

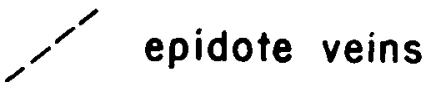

Fig. 9. Geologic map of dikes, lavas, and hydrothermal mineralogy at a prehnite mineralized dike located 10 kilometers west of Kap Irminger (see fig. 8). The irregular black structures within the mineralized dike denote large cavities that are partially filled with prehnite (see fig. 10A).

youngest intrusives in any given area (fig. 9). Alteration consists of a pervasive replacement of plagioclase and groundmass by prehnite, and localized mineralization in veins and large $(<0.3$ meter wide) cavities. The cavity lining prehnite commonly has a well developed botryoidal habit (in fig. 10A). An 11 meter wide dike at Kap Irminger contains a number of interconnected cavities up to 0.3 meters wide, lined with euhedral green prehnite that have epidote and titanite overgrowths. Other associated minerals are acti- nolite, stilpnomelane, albite, sulphides, copper silicates, and relict clinopyroxenes. Calcite is often found as a late stage mineral partially filling the cavities. Prehnite mineralized dikes show a progressive increase in degree of alteration towards their centers. The margins are chilled against surrounding dikes or lavas and appear unaltered relative to the interior portions of the dike. The abundance of metasomatic prehnite mineralization is variable along the length of the dike, with areas of intense prehnite replacement 

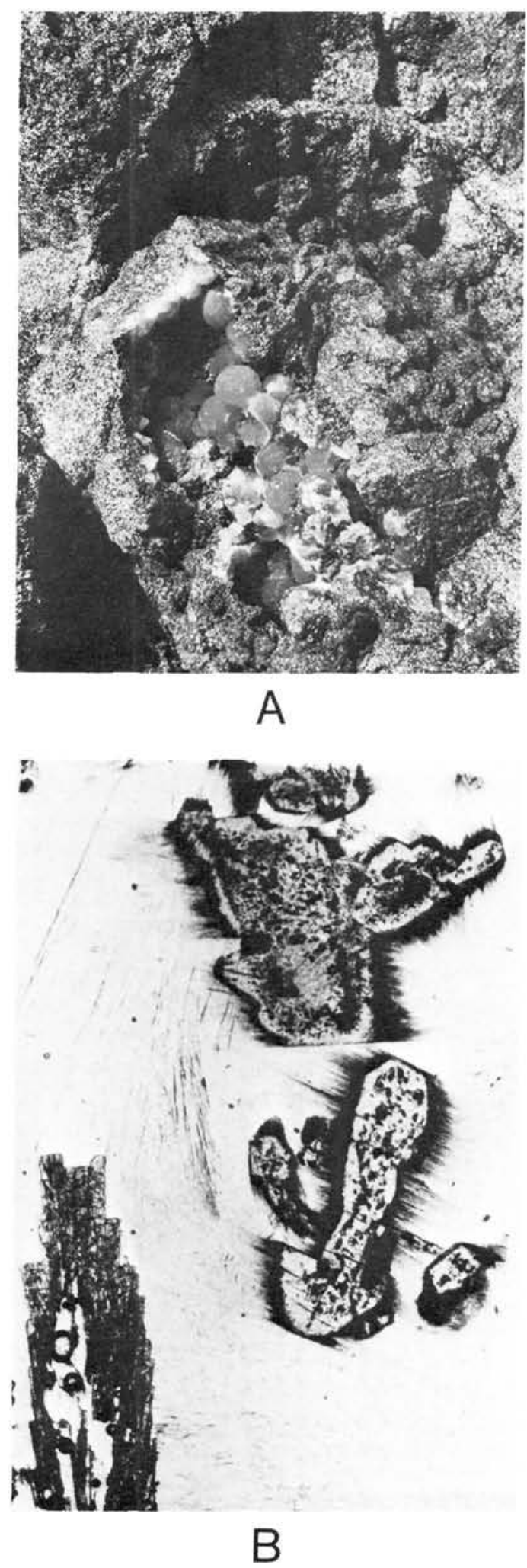

being less than 50 meters in length. This replacement pattern probably indicates that some portions of the dike were more permeable to the flow of mineralizing fluids.

Fig. 10B illustrates the fabric of the prehnite groundmass that surrounds sheaths of euhedral epidote and partially altered anhedra of clinopyroxene in a sample from a mineralized cavity at the Miki Fjord locality (sample provided by T. F. D. Nielsen, GGU). No igneous textures are preserved. Representative chemical analyses of these minerals are reported in Table 1. The calcium-pyroxenes have inclusion-rich cores, are usually rounded, and sometimes show evidence of brecciation. The cores of the pyroxenes are usually inclusion-rich. Measured compositions are shown on the pyroxene quadrilateral in fig. 11 , where it can be seen that the cores are augites with less than 30 mole $\% \mathrm{CaSiO}_{3}$, while the rims are more calcic. It is generally found that the ratio of $\mathrm{Fe}$ to $\mathrm{Mg}$ decrases towards the rims, although one analysis of an overgrowth on an augite grain is notably more iron rich (fig. 11). Pyroxenes are surrounded by the prehnite groundmass and have epitaxial overgrowths of thin needles that may be actinolite (fig. 10B).

Prehnite compositions from the dike are variable, ranging from $\mathrm{X}_{\mathrm{Ca}_{2} \mathrm{FeAlS}_{3} \mathrm{O}_{10}(\mathrm{OH})_{2}}=0.05$ to 0.41 . Iron rich prehnites are more abundant. No systematic zoning has been identified. Epidotes have a more limited range of $\mathrm{Fe}^{+++}$substitution for $\mathrm{Al}^{+++}$, with compositions between $\mathrm{X}_{\mathrm{Ca}_{2} \mathrm{Fe}_{3} \mathrm{Si}_{3} \mathrm{O}_{12}(\mathrm{OH})_{2}}=0.185$ to 0.258 . The partitioning of ferric iron between epidote and prehnite across grain boundaries is also highly variable, suggesting that equilibrium has not been attained between the two minerals.

Thermodynamic analysis of prehnite stability in the system $\mathrm{CaO}-\mathrm{Fe}_{2} \mathrm{O}_{3}-\mathrm{Al}_{2} \mathrm{O}_{3}-\mathrm{SiO}_{2}-\mathrm{H}_{2} \mathrm{O}$ allows evaluation of possible conditions that pre-

Fig. 10. (A) Photograph of a 30 centimer wide prehnite lined cavity in a prehnite mineralized dike at Kap Irminger. The cavities form an interconnected network in the center of the dike. They are lined with botryoidal prehnite with epidote growing on their outer edges. (B) Photomicrograph of cavity filling minerals from the Miki Fjord prehnite mineralized dike showing the textural relations between colorless prehnite matrix epidote (lower left) and clinopyroxene (top and center). The clinopyroxenes are rimmed by overgrowths of an alteration product, probably actinolite. Width of the microphotograph is $3.5 \mathrm{~mm}$. 
Table 1: Representative Analyses of Minerals from a Prehnite Mineralized Dike at Miki Fjord (fig. 8) ${ }^{1}$

\begin{tabular}{|c|c|c|c|c|c|}
\hline & $\begin{array}{l}\text { Cpx }{ }^{2} \\
\text { PD37 }\end{array}$ & $\begin{array}{l}\text { Cpx }{ }^{3} \\
\text { PD28 }\end{array}$ & $\begin{array}{c}\text { Epid }^{4} \\
\text { PD2 }\end{array}$ & $\begin{array}{l}\text { Pren }^{5} \\
\text { PD3 }\end{array}$ & $\begin{array}{l}\text { Pren } \\
\text { PD21 }\end{array}$ \\
\hline $\mathrm{SiO}_{2}$ & 51.85 & 52.28 & 38.77 & 43.97 & 43.39 \\
\hline $\mathrm{Al}_{2} \mathrm{O}_{3}$ & 2.31 & 1.70 & 26.33 & 23.44 & 18.67 \\
\hline $\mathrm{FeO}$ & 8.96 & 14.14 & 0.00 & 0.00 & 0.00 \\
\hline $\mathrm{Fe}_{2} \mathrm{O}_{3}$ & 0.00 & 0.00 & 9.15 & 1.06 & 7.51 \\
\hline $\mathrm{MgO}$ & 14.26 & 14.89 & 0.03 & 0.12 & 0.42 \\
\hline $\mathrm{MnO}$ & 0.19 & 0.42 & 0.02 & 0.00 & 0.00 \\
\hline $\mathrm{TiO}_{2}$ & 0.87 & 0.75 & 0.16 & 0.00 & 0.00 \\
\hline $\mathrm{Cr}_{2} \mathrm{O}_{3}$ & 0.00 & 0.02 & 0.00 & 0.00 & 0.00 \\
\hline $\mathrm{CaO}$ & 21.52 & 15.71 & 24.17 & 27.07 & 26.02 \\
\hline $\mathrm{Na}_{2} \mathrm{O}$ & 0.00 & 0.00 & 0.00 & 0.00 & 0.00 \\
\hline SUM & 99.96 & 99.89 & 97.70 & 95.66 & 96.01 \\
\hline Si & 1.932 & 1.962 & 3.017 & 3.027 & 3.044 \\
\hline $\mathrm{Al}^{\mathrm{IV}}$ & 0.068 & 0.038 & 0.000 & 1.904 & 1.545 \\
\hline $\mathrm{Al}^{\mathrm{VI}}$ & 0.033 & 0.037 & 2.417 & 0.000 & 0.000 \\
\hline $\mathrm{Fe}^{2+}$ & 0.279 & 0.444 & 0.000 & 0.000 & 0.000 \\
\hline $\mathrm{Fe}^{3+}$ & 0.000 & 0.000 & 0.536 & 0.055 & 0.397 \\
\hline $\mathrm{Mg}$ & 0.792 & 0.833 & 0.003 & 0.012 & 0.044 \\
\hline Mn & 0.006 & 0.013 & 0.013 & 0.000 & 0.000 \\
\hline $\mathrm{Ti}$ & 0.024 & 0.021 & 0.009 & 0.000 & 0.000 \\
\hline $\mathrm{Cr}$ & 0.000 & 0.001 & 0.000 & 0.000 & 0.000 \\
\hline $\mathrm{Ca}$ & 0.859 & 0.632 & 2.015 & 1.997 & 1.956 \\
\hline $\mathrm{Na}$ & 0.000 & 0.000 & 0.000 & 0.000 & 0.000 \\
\hline SUM & 3.993 & 3.980 & 7.998 & 6.995 & 6.986 \\
\hline
\end{tabular}

1. All analyses were performed on the Stanford University JEOL 377 automated electron microprobe with 5 spectrometers. A sample current of $15 \mathrm{nA}$ and $15 \mathrm{Kv}$ accelerating voltage were used, with 20 seconds maximum counting time and beam diameters of 1-3 microns. The Bence \& Albee (1968) matrix correction method and Albee \& Ray (1970) correction factors were employed.

2. Calcium Clinopyroxene, rim. 3. Calcium Clinopyroxene, core. 4. Epidote. 5. Prehnite.

vailed during mineralization. The stability of prehnite is limited to temperatures less than $400^{\circ} \mathrm{C}$, where it breaks down to clinozoisite, grossular, quartz and fluid (Liou 1971). Substitution of $\mathrm{Fe}^{+++}$for $\mathrm{Al}^{+++}$in prehnite, epidote, and garnet reduces this temperature (Bird \& Helgeson 1980, 1981).

The two logarithmic activity diagrams shown in fig. 12 illustrate the stability of prehnite and other calc-silicates in terms of the cation activities expressed as $\mathrm{a}_{\mathrm{Ca}^{++}} / \mathrm{a}^{2} \mathrm{H}^{+}$and $\mathrm{a}_{\mathrm{Fe}^{++}}{ }^{++} / \mathrm{a}^{3} \mathrm{H}^{+}$in the hydrothermal solutions (cf. Helgeson 1970). The stability of prehnite, epidote and grandite garnet solid solutions are shown by dot-dashed lines that represent the equilibrium relations between calcsilicate mineral compositions and the thermodynamic activities of $\mathrm{Ca}^{++}, \mathrm{Fe}^{+++}$and $\mathrm{H}^{+}$in the hydrothermal solutions at $350^{\circ}$ and $200^{\circ} \mathrm{C}$ and 500 bars fluid pressure. Note that the stability of prehnite is strongly influenced by $\mathrm{a}_{\mathrm{Fe}}{ }^{++} / \mathrm{a}^{3} \mathrm{H}^{+}$in the aqueous phase. In natural systems this will in turn be controlled by the oxygen fugacity, $\mathrm{pH}$ and the total concentration of iron in the fluid. With increased $\mathrm{a}_{\mathrm{Fe}^{+++}} / \mathrm{a}^{3} \mathrm{H}^{+}$ratio in the fluid the stability field of prehnite is replaced by that of epidote and grandite garnet, both of which can accept more octahedral $\mathrm{Fe}^{+++}$substitution for $\mathrm{Al}^{+++}$. At $350^{\circ} \mathrm{C}$ the maximum octahedral ferric iron substitution in prehnite is approximately $5 \%$, but at $200^{\circ} \mathrm{C}$ this increases to $67 \%$ as shown in fig. 12A and B respectively. Many of the analyzed prehnites from the dike sample contain more than $30 \%$ iron in the octahedral site, which is stable in the presence of an aqueous solution only at temperatures less than about $250^{\circ} \mathrm{C}$.

It is apparent from the phase diagrams in fig. 12 that prehnite mineralization in these dikes probably occurred in the presence of low temperature $\left(<250^{\circ} \mathrm{C}\right)$ hydrothermal solutions. These fluids were not oxidizing enough to stabilize grandite garnet in the presence of epidote. The compositions of the pyroxenes are too calciumpoor to be compatible with this low temperature alteration (e.g. Lindsley 1983). The pyroxene rim compositions must either represent partial alteration at low temperatures, or equilibration of the rims during a higher temperature alteration episode.

Using the computational method of Bird et al. (1984), an estimate of the oxygen fugacity defined by the dike assemblage of clinopyroxene, prehnite and epidote is between $10^{-46}$ and $10^{-48}$ bars at $200^{\circ} \mathrm{C}$. These fugacities are slightly below the quartz-fayalite-magnetite buffer at 500 bars.

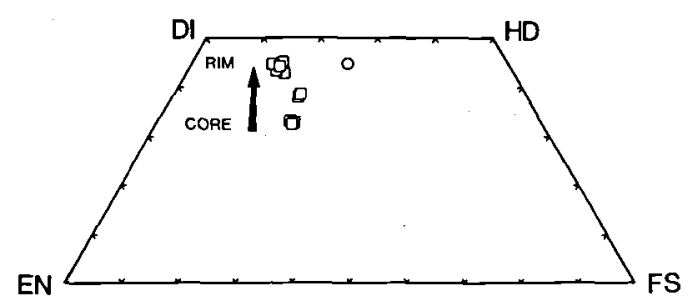

Fig. 11. Measured compositions of clinopyroxenes from the Miki Fjord prehnite mineralized dike, plotted in terms of the normalized quadrilateral components $\mathrm{MgSiO}_{3}(\mathrm{EN}), \mathrm{FeSiO}_{3}$ (FS) $\mathrm{CaFeSi}_{2} \mathrm{O}_{6}$ (HD) and $\mathrm{CaMgSi}_{2} \mathrm{O}_{6}$ (DI). The calcium rich and calcium poor group, both shown by squares, represent analyses from rim and core respectively. The circle represents an analysis from an overgrowth. 

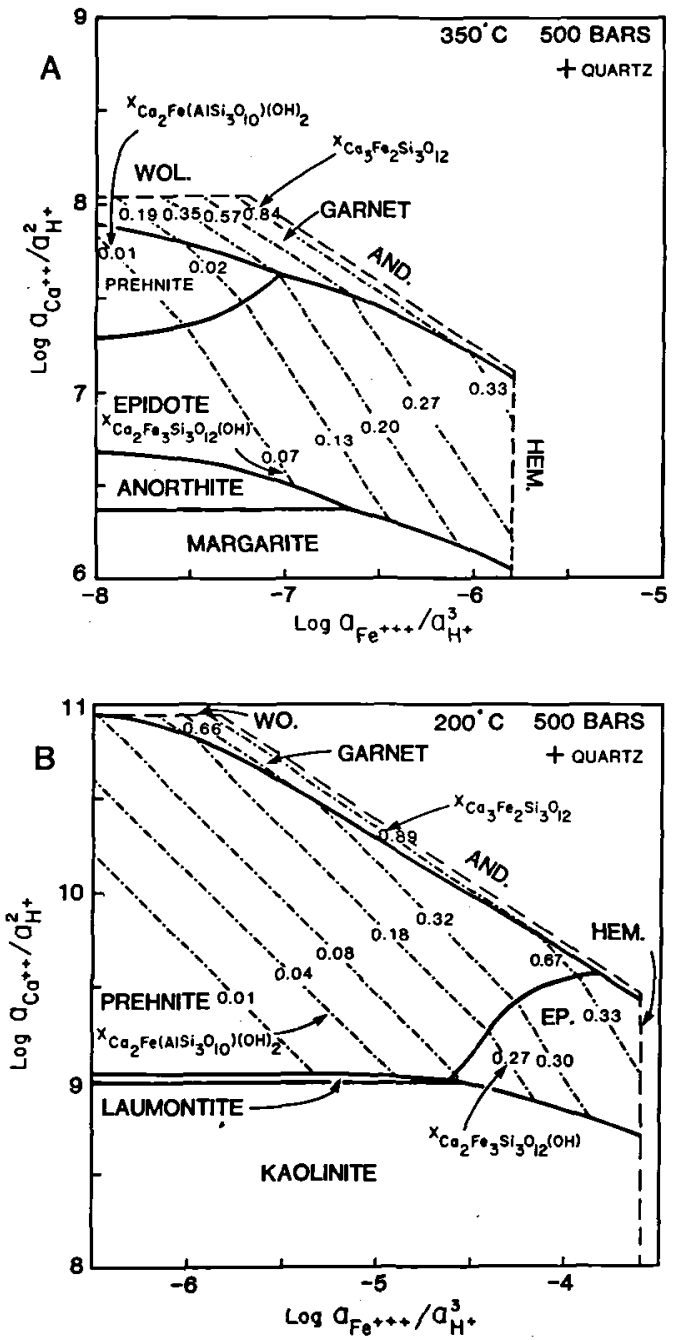

Fig. 12. Activity - activity phase diagram showing the stability of prehnite as a function of the activities of $\mathrm{Ca}^{++}, \mathrm{Fe}^{+++}$and $\mathrm{H}^{+}$in the coexisting hydrothermal solution in equilibrium with quartz. The thick broken lines denote saturation in the fluid phase with either wollastonite (WOL.) andradite (AND.), or hematite (HEM). The thin broken lines represent isopleths of constant composition of prehnite, garnet or epidote solid solutions. These diagrams are calculated from equations and data reported by Bird \& Helgeson (1980; 1981), Helgeson et al. (1978; 1981), Helgeson \& Kirkham (1974a,b; 1976), and Walther \& Helgeson (1977). The boundary between prehnite and epidote solid solutions was calculated using a $\log \mathrm{K}$ of -1.27 for the reaction epidote + prehnite $=$ clinozoisite + Fe-prehnite, this value was found to fit data from geothermal systems reported by Bird et al. (1984). These diagrams illustrate that iron rich prehnites such as those found in the prehnite mineralized dikes are only stable at temperatures below about $250^{\circ} \mathrm{C}$.

This represents the oxygen fugacity that would exist if the system was buffered by metastable equilibria of prehnite, epidote and clinopyrox- ene. Aqueous solutions with these characteristics could have been derived from the reactions of acidic hydrothermal solutions with rock units rich in calcic plagioclase below the mineralized dikes, such as basic intrusives or tonalitic gneisses. Prehnite mineralized dikes may represent highangle permeable conduits that acted as upflow zones for hydrothermal solutions associated with the cooling of deeper mafic intrusions. However, it should be pointed out that other causes of alteration of these dikes are possible. For example, Elsdon (1982) proposes a process of autometasomatism for the intense calc-silicate mineralization in the Kap Edvard Holm Complex, arguing that the intrusion has reacted with a volatile-rich phase which has separated from the magma and remained trapped within the walls of the intrusion.

\section{Concluding remarks}

The Miki Fjord area of East Greenland provides excellent outcrops for the study of the physical and chemical processes that characterize magma emplacement associated with continental break up. Our studies have documented the effect of interactions between the varied types of mafic intrusions and their associated hydrothermal systems with the Precambrian basement complex and the thick sequence of plateau basalts.

Our ongoing studies will complement other geological, geochemical, and geophysical investigations of hydrothermal processes associated with high level igneous intrusions in regions of crustal rifting such as the Salton Trough of California and Mexico, Iceland, and mid ocean ridge spreading centers.

Acknowledgements. The success of the 1984 Stanford University East Greenland expedition was dependent on the help and advice of many people. We give special thanks to Troels F. D. Nielsen (GGU), C. K. Brooks and D. Bridgwater, (University of Copenhagen), T. I. Hauge Andersson (Geodætisk Institut), Sigurdur Adalsteinsson (F. N., Akureyri, Iceland, Stefan Arnórrson (University of Iceland), Ingvar B. and Gudmundur $O$. Fridleifsson (National Energy Authority, Iceland), Elaine Padovanni and Alan Gaines of the U.S. National Science Foundation, and J. C. Ingle Jr., Chuck Karish, Janet Wright, Debbie Montgomery, Halldora Hreggvidsdottir and Barbara Bishop at Stanford University. We also benefited from the cooperative and professional action of Flugfelag Nordurlands, Akureyri and Statens Luftfartsvæsen at Mestersvig Airport. The manuscript was reviewed by Ella Hoch and C. Kent Brooks, whose comments greatly improved the content of the paper. 
This research is funded by the National Science Foundation (NSF-EAR 82-15120 and NSF-EAR 84-18129), the School of Earth Sciences at Stanford University, the Carlsberg Foundation and the Danish Natural Sciences Research council. Support from the Shell Oil Company and a Geological Society of America Penrose Grant (C.E.M.) are also gratefully acknowledged.

\section{Dansk sammendrag}

Miki Fjord området i det centrale $\emptyset$ stgrønland udgøres af Prækambrisk grundfjeld overlejret af Kridt-Tertiær sedimenter og Tertiare plateaubasalter. Grundfjeldet og de Phanerozoiske supracrustaler er intruderet af talrige gabbroiske og doleritiske intrusiver, hvoraf Skærgårdsintrusionen og de kystparalelle gange er de mest prominente.

Vekselvirkning mellem områdets intrusiver og deres værtsbjergarter er udbredt,og ses dels $\mathrm{i}$ form at hydrothermale årer $\mathrm{i}$ basalter og intrusiver, dels $\mathrm{i}$ form af blandingsbjergarter dannet ved opbrydning og delvis opsmeltning af intrusivernes sidesten. I en øst-vest gående zone er observeret enkelte doleritiske gange indeholdende op til $60 \%$ xenolither, overvejende af gnejs men med enkelte blokke af leucogabbro.

En serie gabbroiske gange (makrodikes) indeholder store mængder partielt opsmeltede gnejs enklaver, koncentreret nær toppen af intrusionerne.

Regional metamorfose af basalterne i området nåede zeolit greenschist facies.

Den regionalmetamorfe mineralogi er modificeret op mod kontakten til de senere intrusiver, ligesom lateralt udbredte stratigrafiske niveauer med afvigende metamorf mineralogi findes. De anormale områder har strukturer og mineralogi tolket som værende dannet $i$ overfladenære hydrotermal felter, $i$ forbindelse med basaltiske intrusiver.

Talrige doleritiske gange med hydrotermalt omdannede centre bestående af prehnit-epidot bjergarter med relikte pyroxener er observeret. Disse gange indikerer kraftig lokal Ca-metasomatose.

\section{References}

Albee, A. L. \& Ray, L, 1970: Correction factors for electron probe microanalysis of silicates, oxides, carbonates, phosphates and sulfates. Anal. Chem. 42: 1408-1414.

Basaltic Volcanism Study Project 1981: Basaltic volcanism on the terrestrial planets. Pergamon Press, New York, 1086 pp.

Bence, A. E. \& Albee, A: L. 1968: Empirical correction factors for the electron microanalysis of silicates and oxides. J. Geol. 76: 382-403.

Bird, D. K. \& Helgeson, H. C. 1980: Chemical interaction of aqueous solutions with epidote-feldspar mineral assemblages in geologic systems. I. Thermodynamic analysis of phase relations in the system $\mathrm{CaO}-\mathrm{FeO}-\mathrm{Fe}_{2} \mathrm{O}_{3}-\mathrm{Al}_{2} \mathrm{O}_{3}-$ $\mathrm{SiO}_{2}-\mathrm{H}_{2} \mathrm{O}-\mathrm{CO}_{2}$. Am. J. Sci. 280: 907-941.

Bird, D. K. \& Helgeson, H. C. 1981: Chemical interaction of aqueous electrolyte solutions with epidote-feldspar mineral assemblages in geologic systems. II. Equilibrium constraints in metamorphic/geothermal processes. Am. J. Sci. 281: $576-614$.

Bird, D. K. \& Rogers, R. D. 1983: Fracture controlled hydrothermal alterations of the Skaergaard intrusion, Kangerdlugssuaq, East Greenland. Geol. Soc. Am. Abstr. with Programs 15: 526
Bird, D. K. \& Manning, C. E. 1984: Mineralogic record of hydrothermal fluid flow in the layered series of the Skaergaard intrusion. Geol. Soc. Am. Abstr. with Programs 16: 445 .

Bird, D. K., Schiffman, P., Elders, W. A., Williams, A. E., \& McDowell, S. D. 1984: Calc-silicate mineralization in active geothermal systems. Econ. Geol. 79: 671-695.

Blank, H. R. \& Gettings, M. E. 1973: Gravity survey and subsurface structure of the Skaergaard intrusion. EOS (Trans. Am. Geophys. Union) 6000.

Bridgwater, D., Davies, F. B., Gill, R. C. O., Gorman, B. E., Myers, J. S., Pederson, S., \& Taylor, P., 1978a: Precambrian and Tertiary geology between Kangerdlugssuaq and Angmagssalik, east Greenland. Rapp. Gronlands geol. Unders. 83: $17 \mathrm{pp}$.

Bridgwater, D., Davies, F. B., Gill, R. C. O., Gorman, B. E., Myers, J. S., Pederson, S., \& Taylor, P., 1978b: Field work between Kangerdlugssuaq and Angmagssalik $\emptyset$, souther east Greenland. Rapp. Gronlands geol. Unders. 90: 87-89.

Bridgwater, D., Collerson, K. D. \& Myers, J., 1978c: The development of the Archaean gneiss complex of the North Atlantic region. In Tarling, H. D. (edit.): Evolution of the Earth's crust. London: Academic Press. 123-146.

Brooks, C. K., 1973: Rifting and doming in southern East Greenland. Nature (London), Phys. Sci. 244: 23-25.

Brooks, C. K. \& Nielsen, T. F. D. 1982a: The Phanerozoic development of the Kangerdlugssuak area, east Greenland. Meddr. Grønland, Geoscience 9: $30 \mathrm{pp}$.

Brooks, C. K. \& Nielsen, T. F. D. 1982b: The East Greenland continental margin: a transition between oceanic and continental magmatism. J. Geol. Soc. London 139: 265-275.

Coombs, D. S. 1961: Some recent work on the lower grades of metamorphism. Australian J. Sci. 24: 203-215.

Deer, W. A. 1976: Tertiary igneous rocks between Scoresby Sund and Kap Gustav Holm, East Greenland. In: Escher, A. \& Watt, W. S. (eds): Geology of Greenland. Denmark, The Geological Survey of Greenland. 405-429.

Elsdon, R. 1982: Autometasomatic alteration of gabbro, Kap Edvard Holm intrusive complex, east Greenland. Mineral. Mag. 45: 219-225.

Evarts, R. C. \& Schiffman, P. 1983: Submarine hydrothermal metamorphism of the Del Puerto ophiolite, California. Am. J. Sci. 283: 289-340.

Faller, A. M. \& Soper, N. J. 1979: Paleomagnetic evidence for the origin of the coastal flexure and dike swarm in central E. Greenland. J. Geol. Soc. London 136: 737-744.

Fawcett, J. J., Brooks, C. K. \& Rucklidge, J. C. 1973: Chemical petrology of Tertiary flood basalts from the Scoresby Sund area. Meddr. Grønland 195 (6): 1-54.

Helgeson, H. C. 1970: Description and interpretation of phase relations in geochemical processes involving aqueous solutions. Am. J. Sci. 268: 415-438.

Helgeson, H. C. \& Kirkham, D. H. 1974a: Theoretical prediction of the thermodynamic behavior of aqueous electrolytes at high pressures and temperatures: I. Summary of the thermodynamic properties of the solvent. Am. J. Sci. 274: 1089-1198.

Helgeson, H. C. \& Kirkham, D. H. 1974b: Theoretical prediction of the thermodynamic behavior of aqueous electroly. tes at high pressures and temperatures: II. Debye - Huckel parameters for activity coefficients and relative partial molal properties. Am. J. Sci. 274: 1199-1261.

Helgeson, H. C. \& Kirkham, D. H. 1976: Theoretical prediction of the thermodynamic behavior of aqueous electrolytes at high pressures and temperatures. III. Equation of state for aqueous species at infinite dilution. Am. J. Sci. 276: 97-240.

Helgeson, H. C., Delany, J. M., Nesbitt, H. W. \& Bird, D. K. 1978: Summary and critique of the thermodynamic properties of rock-forming minerals. Am. J. Sci. 278-A: 299 pp. 
Helgeson, H. C., Kirkham, D. H. \& Flowers, G. C. 1981: Theoretical prediction of the thermodynamic properties of aqueous electrolytes at high pressures and temperatures: IV. Calculation of activity coefficients, osmotic coefficients, and apparent molal and standard and relative partial molal properties to $600^{\circ} \mathrm{C}$ and 5KB. Am. J. Sci. 281: 1249-1516.

Kays, M. A., McBirney, A. R. \& Goles, G. G. 1981: Xenoliths of gneisses and the unconformable, clot-like granophyres in the Marginal Border Group, Skaergaard intrusion, East Greenland. Contrib. Mineral. Petrol. 76: 265-284.

Kays, M. A. \& McBirney, A. R. 1982: Origin of the picrite blocks in the Marginal Border Group of the Skaergaard intrusion, East Greenland. Geochim. Cosmochim. Acta 46: 23-30.

Kuniyoshi, S. \& Liou, J. G. 1976: Burial metamorphism of the Karmutsen volcanic rocks, northeastern Vancouver Island, British Columbia. Am. J. Sci. 276: 1096-1119.

Larsen, H. C. 1978: Offshore continuation of East Greenland dike swarm and North Atlantic Ocean formation. Nature 274: 220-223.

Larsen, H. C. 1980: Geological perspectives of the East Greenland continental margin. Bull. Geol. Soc. Denmark 29: 77101.

Lindsley, D. H. 1983: Pyroxene thermometry. Am. Min. 68: 477-493.

Liou, J. G. 1971: Synthesis and stability relations of prehnite, $\mathrm{Ca}_{2} \mathrm{Al}_{2} \mathrm{Si}_{3} \mathrm{O}_{10}(\mathrm{OH})_{2}$. Am. Min. 56: 507-531.

Liou, J. G., Maruyana, S. and Cho, M. 1985: Phase equlibria and mineral parageneses of metabolites in low-grade metamorphism. Min. Mag. 49, 32-333.

Manning, C. E. \& Bird, D. K. 1983: Hydrothermal clinopyroxenes of the Skaergaard intrusion, east Greenland. EOS (Trans. Am. Geophys. Union) 64: 904.

McBirney, A. R. 1975: Differentiation of the Skaergaard intrusion. Nature 253: 691-694

McBirney, A. R. 1979: Effects of assimilation. In: Yoder, H. S., JR. (ed.): The evolution of the igneous rocks: fiftieth anniversary perspectives. Princeton, Princeton University Press: $307-329$.

McBirney, A. R. \& Noyes, R. M. 1979: Crystallization and layering of the Skaergaard intrusion. J. Petrol. 20: 487554.

McGregor, V. R. 1973: The early Precambrian gneisses of the Godthaab district, west Greenland. Phil. Trans. R. Soc. London A-273: 343-358.

Myers, J. S. 1980: Structure of the coastal dyke swarm and associated plutonic intrusions of East Greenland. Earth Planet. Sci. Lett. 46: 401-18.

Nielsen, T. F. D. 1975: Possible mechanism of continental breakup in the North Atlantic. Nature 253: 182-184.

Nielsen, T. F. D. 1978: The Tertiary dike swarm of the Kangerdlugssuaq area, east Greenland. Contrib. Mineral. Petrol. 67: 63-78.

Nielsen, T. F. D. \& Brooks, C. K. 1981: The E. Greenland rifted continental margin: an examination of the coastal flexure. J. Geol. Soc. London 138: 559-568.
Nielsen, T. F. D., Soper, N. J., Brooks, C. K., Faller, A. M. Higgins, A. C. \& Matthews, D. W. 1981: The pre-basaltic sediments and the lower basalts at Kangerdlugssuak, east Greenland. Meddr. Grønland, Geoscience 6: $28 \mathrm{pp}$.

Norton, D. \& Taylor, H. P. 1979: Quantitative simulation of the hydrothermal systems of crystallizing magmas on the basis of transport theory and oxygen isotope data: an analysis of the Skaergaard intrusion. J. Petrol. 20: 421-486.

Norton, D., Taylor, H. P. \& Bird, D. K. 1984: The geometry and high temperature brittle deformation of the Skaergaard intrusion. J. Geophys. Res. 89: 10,178-10,192.

Rogers, R. D. \& Bird, D. K. 1983: Deformation associated with emplacement of tholeiitic dikes in the Kangerdlugssuak region of East Greenland. Geol. Soc. Am. Abstr. with Programs 15: 673.

Rogers, R. D. \& Bird, D. K. 1984: Fracture distribution near dike margins in the Skaergaard intrusion. EOS (Trans. Am. Geophys. Union) 65: 282.

Simmons, E. L., Hanson, G. N. \& Lumbers, S. B. 1980: Geochemistry of the Shawmere anorthosite complex, Kapuskasing Structural Zone, Ontario. J. Precambrian Res. 11: 43 71.

Soper, N. J., Higgins, A. C., Downie, C., Matthews, D. W. \& Brown, P. E. 1976a: Late Cretaceous - Early Tertiary stratigraphy of the Kangerdlugssuak area, east Greenland and the opening of the northeast Atlantic. J. Geol. Soc. London 132: 85-102.

Soper, N. J., Downie, C., Higgins, A. C. \& Costa, L. I. 1976b: Biostratigraphic ages of Tertiary basalts on the east Greenland continental margin and their relationship to plate separation in the northeast Atlantic. Earth Planet. Sci. Lett. 32: 149-157.

Taylor, H. P. \& Forester, R. W. 1979: An oxygen isotope study of the Skaergaard intrusion and its country rocks: a description of a 55-m.y. old fossil hydrothermal system. $J$. Petrol. 20: 355-419.

Wager, L. R. 1934: Geological investigations in east Greenland Pt. 1. General geology from Angmagsalik to Kap Dalton. Meddr. Gronland 105: $46 \mathrm{pp}$.

Wager, L. R. 1947: Geological investigations in east Greenland Pt. IV. The stratigraphy and tectonics of Knud Rasmussens Land and the Kangerdlugssuaq region. Meddr. Grønland 134: $62 \mathrm{pp}$.

Wager, L. R. \& Brown, G. M. 1967: Layered Igneous Rocks. San Francisco, W. H. Freeman. 588 pp.

Wager, L. R. \& Deer, W. A. 1938: A dyke swarm and crustal flexure in East Greenland. Geol. Mag. 134: 39-46.

Wager, L. R. \& Deer, W. A. 1939: Geological investigations in east Greenland, Part 3. The petrology of the Skaergaard intrusion, Kangerdlugssuak region. Meddr. Grønland 105: $352 \mathrm{pp}$.

Walther, J. V. \& Helgeson, H. C. 1977: Calculation of the thermodynamic properties of aqueous silica and the solubility of quartz and its polymorphs at high pressures and temperatures. Am. J. Sci. 277: 1315-1351. 